\title{
A new species of Psychrophrynella (Amphibia, Anura, Craugastoridae) from the humid montane forests of Cusco, eastern slopes of the Peruvian Andes
}

Alessandro Catenazzi, Alex Ttito

We describe a new species of Psychrophrynella from the humid montane forest of the Department Cusco in Peru. Specimens were collected at 2670-3165 m elevation in the Área de Conservación Privada Ukumari Llakta, Japumayo valley, near Comunidad Campesina de Japu, in the province of Paucartambo. The new species is readily distinguished from all other species of Psychrophrynella but $P$. bagrecito and $P$. usurpator by possessing a tubercle on the inner edge of the tarsus, and from these two species by its yellow ventral coloration on abdomen and limbs. Furthermore, the new species is like $P$. bagrecito and $P$. usurpator in having an advertisement call composed of multiple notes, whereas other species of Psychrophrynella whose calls are known have a pulsed call ( $P$. teqta) or a short, tonal call composed of a single note. The new species has a snout-vent length of 16.1-24.1 mm in males and 23.3-27.7 mm in females. Like other recently described species in the genus, this new Psychrophrynella inhabits high-elevation forests in the tropical Andes and likely has a restricted geographic distribution. 
1 A new species of Psychrophrynella (Amphibia, Anura, Craugastoridae) from the humid

2 montane forests of Cusco, eastern slopes of the Peruvian Andes

3

4 Alessandro Catenazzi ${ }^{1,2} \&$ Alex Ttito $^{3}$

5

61 Department of Zoology, Southern Illinois University Carbondale, Carbondale, Illinois, USA; 2

7 Centro de Ornitología y Biodiversidad, Lima, Perú; 3 Museo de Historia Natural, Universidad

8 Nacional de San Antonio Abad, Cusco, Perú

9

10

11 Corresponding author: Alessandro Catenazzi (acatenazzi@siu.edu) 


\section{Abstract}

13 We describe a new species of Psychrophrynella from the humid montane forest of the Department Cusco in Peru. Specimens were collected at 2670-3165 m elevation in the Área de Conservación Privada Ukumari Llakta, Japumayo valley, near Comunidad Campesina de Japu, in the province of Paucartambo. The new species is readily distinguished from all other species of Psychrophrynella but $P$. bagrecito and $P$. usurpator by possessing a tubercle on the inner edge of the tarsus, and from these two species by its yellow ventral coloration on abdomen and limbs. Furthermore, the new species is like P. bagrecito and P. usurpator in having an advertisement call composed of multiple notes, whereas other species of Psychrophrynella whose calls are known have a pulsed call (P. teqta) or a short, tonal call composed of a single note. The new species has a snout-vent length of $16.1-24.1 \mathrm{~mm}$ in males and $23.3-27.7 \mathrm{~mm}$ in females. Like other recently described species in the genus, this new Psychrophrynella inhabits high-elevation forests in the tropical Andes and likely has a restricted geographic distribution.

\section{Resumen}

Describimos una nueva especie de Psychrophrynella de los bosques nublados de la Región Cusco en Perú. Los especímenes fueron colectados a una elevación de 2670-3165 m en el Área de Conservación Privada Ukumari Llakta, valle del río Japumayo, cerca de la Comunidad Campesina de Japu, en la provincia de Paucartambo. La nueva especie se diferencia fácilmente de todas las demás especies de Psychrophrynella a excepción de P. bagrecito y $P$. usurpator por poseer un tubérculo en el lado interior del tarso, y se diferencia de estas dos especies por su coloración ventral amarilla en el abdomen y en las patas. Además la nueva especie se asemeja a 
35 P. bagrecito y P. usurpator por tener un canto de anuncio compuesto por múltiples notas,

36 mientras que las demás especies de Psychrophrynella cuyos cantos son conocidos tienen un

37 canto pulsado (P. teqta) o un canto corto no pulsado compuesto por una única nota. La nueva

38 especie tiene una longitud hocico-cloaca (LHC) de 16.1-24.1 mm en machos y de 23.3-27.7

$39 \mathrm{~mm}$ en hembras. Al igual que otras especies recientemente descritas en el género, esta nueva

40 Psychrophrynella habita bosques altoandinos y es probable que tenga una distribución

41 geográfica restringida.

42

43 Key words: bioacoustics, chytrid fungus, frog, cloud forest, leaf litter amphibian, Paucartambo,

44 Psychrophrynella chirihampatu

45

46 Palabras clave: anfibio de hojarasca, bioacústica, hongo quitridio, Paucartambo,

47 Psychrophrynella chirihampatu, rana 


\section{Introduction}

The frog genus Psychrophrynella currently includes 21 species distributed across the humid grasslands and forests from 1830 to 4190 m.a.s.1. in the Amazonian slopes of the Andes in southern Peru and Bolivia (De la Riva and Burrowes 2014; Duellman and Lehr 2009; Frost 2015). The genus was placed within the Holoadeninae in the family Strabomantidae by Hedges et al. (2008), but Pyron and Wiens (2011) synonymized Strabomantidae with Craugastoridae. Only three species are currently known from Peru, but most of the eastern valleys of the Andes in the southern Peruvian regions of Cusco and Puno have been poorly explored and are likely to contain many undescribed species (Catenazzi and von May 2014).

The phylogenetic relationships among the Holoadeninae genera Noblella and Psychrophrynella are not fully resolved. The type species of Psychrophrynella, P. bagrecito (Lynch, 1986) is found in the upper watershed of the Araza river in the Peruvian region of Cusco (Lynch 1986). Despite having been chosen as the type species for the genus by Hedges et al. (2008), P. bagrecito possess several morphological traits that are shared with some species of Noblella, rather than with species of Psychrophrynella (De la Riva et al. 2008a; Lehr 2006). Furthermore, the type species of Noblella, N. peruviana (Noble, 1921) is only known from three type specimens collected from 1899 to 1900 at a Peruvian locality in Region Puno (Noble 1921), and some distinctive traits such as the presence of tubercles might be difficult to discern in long preserved specimens (De la Riva et al. 2008b). Finally, P. bagrecito, P. usurpator, N. lochites, and possibly N. peruviana, according to the original description (Noble 1921), share the unique trait among congeneric species of possessing an elongated tarsal fold.

Surveys in the humid montane forests of the Japumayo Valley in the Region of Cusco, Peru, recently revealed the existence of a species of Psychrophrynella with an elongated tarsal 
71 fold, yellow ventral coloration and a long advertisement call composed of multiple notes, unlike

72 known congeneric species. Here we describe this new species, and we report on surveys of

73 infection with the pathogenic fungus Batrachochytrium dendrobatidis in populations of the new

74 species and of sympatric amphibians. This fungus has caused the collapse of amphibian

75 biodiversity in humid montane forests of the Tropical Andes (Catenazzi et al. 2011; Catenazzi et

76 al. 2014), and could threaten amphibians at the type locality of the new species.

77

\section{Methods}

The format of the diagnosis and description follows Duellman and Lehr (2009) and Lynch and Duellman (1997), except that the term dentigerous processes of vomers is used instead of vomerine odontophores (Duellman et al. 2006). Taxonomy follows Hedges et al. (2008) except for family placement (Pyron and Wiens 2011). Meristic traits of similar species were derived from specimens examined, published photographs, or species descriptions (Table 1).

Specimens were preserved in $70 \%$ ethanol. Sex and maturity of specimens were determined by observing sexual characters and gonads through dissections. We measured the following variables (Table 2) to the nearest $0.1 \mathrm{~mm}$ with digital calipers under a stereomicroscope: snout-vent length (SVL), tibia length (TL), foot length (FL, distance from proximal margin of inner metatarsal tubercle to tip of Toe IV), head length (HL, from angle of jaw to tip of snout), head width (HW, at level of angle of jaw), eye diameter (ED), tympanum diameter (TY), interorbital distance (IOD), upper eyelid width (EW), internarial distance (IND), and eye-nostril distance (E-N, straight line distance between anterior corner of orbit and posterior margin of external nares). Fingers and toes are numbered preaxially to postaxially from 
94 I-IV and I-V respectively. We determined comparative lengths of toes III and V by adpressing 95 both toes against Toe IV; lengths of fingers I and II were determined by adpressing these fingers 96 against each other.

97 We performed Principal Component Analysis on morphological measurements for the

new species and for the morphologically similar Psychrophrynella usurpator (Table 3). We retained five variables to maximize sample size of $\mathrm{n}=17$ for the new species and of $\mathrm{n}=42$ for $P$. usurpator. Morphometric data (non-transformed, after checking for normality) were analyzed with the princomp function using eigen on the correlation matrix in the 'stats' package in R 3.1.3 (The R Foundation for Statistical Computing; http://www.R-project. org). Principal Components 1 and 2 (representing $87 \%$ of variation) were used to produce a scatter plot. Proportion data were arcsine square root transformed for univariate comparisons. Variation in coloration was described on the basis of field notes and photographs of live frogs. Photographs taken by A. Catenazzi of live specimens, including types and non-collected specimens, and of preserved types have been deposited at the Calphoto online database (http://calphotos.berkeley.edu).

We recorded advertisement calls of male CORBIDI 16495 at the type locality on 21 June 2015 and recorded air temperature with a quick reading thermometer (recording \#9843 deposited at the Fonoteca Zoológica, Museo Nacional de Ciencias Naturales, Madrid, www.fonozoo.org). We used a digital recorder (Zoom H2, recording at $48 \mathrm{kHz}, 24$-bit, WAV format) for field recording, and Raven Pro version 1.4 (Cornell Laboratory of Ornithology, Ithaca, NY) to analyze call variables. We analyzed a total of 26 calls. The following variables were measured from oscillograms: note and duration and rate, interval between notes or calls, number of pulses, and presence of amplitude modulation. Variables measured from spectrograms included dominant frequency, and presence of frequency modulation or harmonics. Spectral parameters were 
117 calculated through fast Fourier transform (FFT) set at a length of 512 points (Hann window, 50\%

118 overlap). Averages are reported \pm SD.

119 We estimated genetic distances to confirm generic placement of the new species within

120 Psychrophrynella through analysis of the non-coding 16S rRNA mitochondrial fragment. We

121 used tissues from the holotype, CORBIDI 16495, and from paratopotype MHNC 14664, to

122 obtain DNA sequences for the new species (deposited in GenBank; Appendix 1). We

123 downloaded sequences of congeneric species and of Holoadeninae species in related genera

124 (Barycholos, Bryophryne, Holoaden and Noblella) from GenBank (Appendix 1). Extraction,

125 amplification, and sequencing of DNA followed standard protocols (Hedges et al. 2008). We

126 used the 16Sar (forward) primer (5'-3' sequence: CGCCTGTTTATCAAAAACAT) and the

127 16Sbr (reverse) primer (5'-3' sequence: CCGGTCTGAACTCAGATCACGT) (Palumbi et al.

128 2002). We employed the following thermocycling conditions during the polymerase chain

129 reaction (PCR) with a Veriti thermal cycler (Applied Biosystems): 1 cycle of $96^{\circ} \mathrm{C} / 3 \mathrm{~min} ; 35$

130 cycles of $95^{\circ} \mathrm{C} / 30 \mathrm{~s}, 55^{\circ} \mathrm{C} / 45 \mathrm{~s}, 72^{\circ} \mathrm{C} / 1.5 \mathrm{~min} ; 1$ cycle $72^{\circ} \mathrm{C} / 7 \mathrm{~min}$. PCR products were purified

131 with Exosap-IT (Affymetrix, Santa Clara, CA) and shipped to MCLAB (San Francisco, CA) for

132 sequencing. We used Geneious R8, version 8.1.6 (Biomatters, http://www.geneious.com/) to

133 align the sequences with the MAFFT, version 7.017 alignment program (Katoh and Standley

134 2013). We estimated uncorrected p-distances (i.e., the proportion of nucleotide sites at which any

135 two sequences are different) with the R package "ape” (Paradis et al. 2004).

136 We swabbed specimens in the field to quantify infection by Batrachochytrium

137 dendrobatidis $(\mathrm{Bd})$. Each animal was swabbed with a synthetic dry swab (Medical Wire \&

138 Equipment, \#113) using a standardized swabbing protocol. In post-metamorphic stages, swabs

139 were stroked across the skin a total of 30 times: 5 strokes on each side of the abdominal midline, 
1405 strokes on the inner thighs of each hind leg, and 5 strokes on the foot webbing of each hind leg

141 (total of 30 strokes/frog). We used a real-time Polymerase Chain Reaction (PCR) assay on

142 material collected on swabs to quantify the level of infection (Boyle et al. 2004). DNA was

143 extracted from swabs using PrepMan Ultra and extracts were analyzed in a Life Technologies

144 StepOne Plus qPCR instrument following the protocol outlined in Hyatt et al. (2007) and (Boyle

145 et al. (2004), except that extracts were analyzed once (Kriger et al. 2006). We calculated ZE, the

146 genomic equivalent for Bd zoospores by comparing the qPCR results to a set of standards, and

147 considered any sample with ZE $>1$ to be infected or Bd-positive.

148 Specimens examined are listed in Appendix 2; codes of collections are: CORBIDI =

149 Herpetology Collection, Centro de Ornitología y Biodiversidad, Lima, Peru; MHNC = Museo de

150 Historia Natural del Cusco; KU = Natural History Museum, University of Kansas, Lawrence,

151 Kansas, USA; MUSM = Museo de Historia Natural Universidad Nacional Mayor de San

152 Marcos, Lima, Peru; and MHNG = Muséum d'Histoire Naturelle, Genève, Switzerland.

153 Research was approved by Institutional Animal Care and Use Committees of Southern

154 Illinois University Carbondale (protocols \#13-027). Permit to carry on this research has been

155 issued by the Peruvian Ministry of Agriculture (permit \#292-2014-MINAGRI-DGFFS-

156 DGEFFS). The Comunidad Campesina Japu Q’eros authorized work on their land.

157 The electronic version of this article in Portable Document Format (PDF) will represent a

158 published work according to the International Commission on Zoological Nomenclature (ICZN),

159 and hence the new names contained in the electronic version are effectively published under that

160 Code from the electronic edition alone. This published work and the nomenclatural acts it

161 contains have been registered in ZooBank, the online registration system for the ICZN. The

162 ZooBank LSIDs (Life Science Identifiers) can be resolved and the associated information viewed 
163 through any standard web browser by appending the LSID to the prefix http://zoobank.org/. The

164 LSID for this publication is: urn:lsid:zoobank.org:pub:34FC0393-6723-4554-912A-

165 AEA7ED811589. The online version of this work is archived and available from the following

166 digital repositories: PeerJ, PubMed Central and CLOCKSS.

167

168 Results

169

Psychrophrynella chirihampatu sp. n. urn:Isid:zoobank.org:pub:34FC0393-6723-4554-912A-

AEA7ED811589

171 http://zoobank.org/34FC0393-6723-4554-912A-AEA7ED811589

Holotype (Figs 1-3, Table 2). CORBIDI 16495, an adult male (Figs 2, 3) from 1326'44.92' 'S;

$17471^{\circ} 0^{\prime} 12.35^{\prime \prime} \mathrm{W}$ (WGS84), 2730 m.a.s.1., Área de Conservación Privada (ACP) Ukumari Llaqta, 175 Comunidad Campesina de Japu, Distrito Paucartambo, Provincia Paucartambo, Región Cusco, 176 Peru, collected by A. Catenazzi and A. Ttito on 21 June 2015.

Paratopotypes (Fig. 4, Table 2). Ten total: five adult males, CORBIDI 16496 and 16497 and MHNC 14658, 14664 and 14666 (Figs 2, 3), and five adult females, CORBIDI 1649816499, 16696 and MHNC 14661-14662, collected at the type locality by A. Catenazzi and A. Ttito on 21 June 2015.

Paratypes. (Fig. 4). 16 total, all from ACP Ukumari Llakta: nine adult males, CORBIDI 16505-16509 and MHNC 14656 and 14670-14672, and one adult female, CORBIDI 16504,

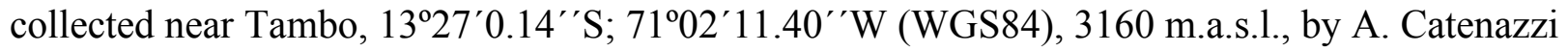
and A. Ttito on 18 June 2015; two adult males, CORBIDI 16503 and MHNC 14667, and four adult females, CORBIDI 16501-2 and MHNC 14668-69, collected at Playa camp site, 
186 187 June 2015.

Generic placement. A new species of Psychrophrynella as defined by (Duellman and

$13^{\circ} 26^{\prime} 53.52^{\prime \prime} \mathrm{S} ; 71^{\circ} 0^{\prime} 38.38^{\prime \prime} \mathrm{W}$ (WGS84), 2780 m.a.s.1., by A. Catenazzi and A. Ttito on 18 Lehr 2009; Hedges et al. 2008). Frogs of the genus Psychrophrynella are morphologically similar and closely related to Barycholos, Bryophryne, Holoaden and Noblella (Hedges et al. 2008; Heinicke et al. 2007; Padial et al. 2014). The new species is assigned to Psychrophrynella rather than any of the other genera on the basis of molecular data (Table 4) and overall morphological resemblance with the type species $P$. bagrecito (see Table 1), including presence of an elongated fold-like tubercle on the inner edge of tarsus. Genetic data confirm generic placement of the new species within Psychrophrynella. We found substantial genetic distances (uncorrected p-distances from 7.2-19.3\%; Table 4) between P. chirihampatu and congeneric species for which mitochondrial sequence data were available. The most closely related species is $P$. usurpator (16S uncorrected p-distance: 7.2\%), followed by $P$. guillei and P. wettsteini which had much higher distances of $17.8-19.3 \%$. Species from other genera (with the exception of $B$. cophites) had genetic distances above $20 \%$.

\section{Diagnosis. A species of Psychrophrynella characterized by (1) skin on dorsum finely}

shagreen with some small warts forming linear ridges at mid dorsum; skin on venter smooth, discoidal fold not visible, thin dorsolateral folds visible on anterior half part of body; (2) tympanic membrane not differentiated, tympanic annulus barely visible below skin; (3) snout short, bluntly rounded in dorsal view and in profile; (4) upper eyelid lacking tubercles, narrower than IOD; cranial crests absent; (5) dentigerous process of vomers absent; (6) vocal slits present; nuptial pads absent; (7) Finger I shorter than Finger II; tips of digits bulbous, not expanded laterally; (8) fingers lacking lateral fringes; (9) ulnar tubercles absent; (10) heel lacking 
209 tubercles; inner edge of tarsus bearing an elongate, obliquous fold-like tubercle; (11) inner

210 metatarsal tubercle prominent, elliptical, of higher relief and about one and a half times the size

211 of ovoid, outer metatarsal tubercle; supernumerary plantar tubercles absent; (12) toes lacking

212 lateral fringes; webbing absent; Toe V slightly shorter than or about the same length as Toe III;

213 tips of digits not expanded, weakly pointed; (13) dorsum tan to brown and gray with dark brown

214 markings; some individuals with a yellow or orange middorsal line extending from tip of snout

215 to cloaca and to posterior surface of thighs; interorbital bar present; chest, venter and ventral

216 parts of arms and legs yellow with brown flecks; throat and palmar and plantar surfaces brown or

217 reddish-brown; (14) SVL 16.1-24.1 in males $(n=34), 23.3-27.7$ in females $(n=12)$.

Comparisons. The new species differs from most described species in the genus by possessing an elongate fold-like tubercle on the inner edge of tarsus. Among currently known species in the genus, only the two Peruvian, and geographically closest species $P$. bagrecito and P. usurpator possess such a tubercle, which is similarly shaped (obliquous) in the latter but sickle-shaped in P. bagrecito. The other Peruvian species, $P$. boettgeri, and all species described from Bolivia (including P. guillei, P. katantika, P. kallawaya and P. saltator known from the Cordillera de Aplobamba near the border with Peru; Fig. 1) lack a tubercle or fold on the inner edge of tarsus. Furthermore, among species whose advertisement calls is known, $P$. chirihampatu shares with $P$. bagrecito, $P$. saltator and $P$. usurpator the characteristic of having a call composed of multiple notes (Table 1; unpublished data for calls of P. bagrecito and $P$. usurpator), whereas the call is pulsed in P. teqta or composed of short, single notes in other congeneric species (De la Riva 2007; De la Riva and Burrowes 2014). Morphologically, the new species is most similar to P. usurpator (characters in parentheses; Table 1), from which it differs by having yellow ventral coloration with reddish- 
232 brown or grey flecks (dull brown, gray or black with cream flecks), Finger I shorter than Finger

233 II (slightly shorter or same length), smaller SVL reaching $27.5 \mathrm{~mm}$ in females (SVL up to 30.5

$234 \mathrm{~mm}$ ), slender head (wider and shorter head), and inner metatarsal tubercle at least three times the

235 size of outer metatarsal tubercle (about same size). The scatterplot of the first two Principal

236 Components axes reveal that these two species occupy distinct regions of morphospace (Fig.

237 5A). Snout-vent length and tibia length load strongly on the first Principal Component axis PC1,

238 whereas head width and foot length load strongly on the second Principal Component, PC2

239 (Table 3). Univariate comparisons of measurements of male P. chirihampatu and P. usurpator

240 reveal that male $P$. chirihampatu have narrower heads, averaging $35.4 \%$ of SVL (HW $38.0 \%$ of

241 SVL in P. usurpator; $\mathrm{t}_{57}=-5.12, \mathrm{p}<0.001$; Fig. 5B), and longer tibia length, averaging $46.7 \%$ of

242 SVL (TL $45.2 \%$ of SVL, $\left.\mathrm{t}_{57}=2.24, \mathrm{p}=0.01\right)$, but no difference in foot length $\left(\mathrm{t}_{57}=1.44, \mathrm{p}=\right.$

$2430.08)$.

244 We also compared the new species with the type species of Psychrophrynella, $P$.

245 bagrecito (Lynch, 1986). Psychrophrynella chirihampatu differs from P. bagrecito (characters in

246 parentheses; Table 1) in having an elongated and oblique fold-like tarsal tubercle (short and

247 sickle-shaped), broad dark markings on dorsum (longitudinal stripes), venter yellow with dark

248 flecks (venter orange brown with light gray flecks) and larger size of females up to $27.5 \mathrm{~mm}$ in

249 SVL (SVL of females up to $19.0 \mathrm{~mm}$ ).

250 Ten other small species of craugastorid frogs of the subfamily Holoadeninae are known

251 to occur in montane forests and high Andean grasslands south of the Apurimac canyon in Peru:

252 Bryophryne abramalagae, B. bustamantei, B. cophites, B. flammiventris, B. gymnotis, B.

253 hanssaueri, B. nubilosus, B. zonalis, Noblella madreselva and N. pygmaea. None of these species 
254 has the unique ventral coloration of $P$. chirihampatu, and all but B. gymnotis and the two species

255 of Noblella (which are much smaller in size) lack a visible tympanic annulus.

256

257

258

259

260

261

262

263

264

265

266

267

268

269

270

271

272

273

274

275

276

Description of holotype. Adult male (18.8 mm SVL); head narrower than body, its length $39.9 \%$ of SVL; head slightly longer than wide, head length $110.3 \%$ of head width; head width $36.2 \%$ of SVL; snout short, bluntly rounded in dorsal and lateral views (Fig. 2), eye diameter $26.7 \%$ of head length, its diameter 1.1 times as large as its distance from the nostril; nostrils not protuberant, close to snout, directed laterally; canthus rostralis slightly concave in dorsal view, convex in profile; loreal region flat; lips rounded; upper eyelids without tubercles; upper eyelid width $59.1 \%$ of interorbital distance; interorbital region flat, lacking cranial crests; eye-nostril distance $90 \%$ of eye diameter; supratympanic fold weak; tympanic membrane not differentiated, tympanic annulus visible below skin; two small postrictal ridges on each side of head. Vocal sac and vocal slits present. Choanae round, small, positioned far anterior and laterally, widely separated from each other; dentigerous processes of vomers and vomerine teeth absent; tongue large, ovoid, not notched.

Skin on dorsum smooth with minute, scattered tubercles, denser posteriorly; barely visible dorsolateral folds anteriorly; skin on flanks and venter smooth; no pectoral fold, barely visible discoidal fold; cloaca not protuberant, cloacal region without tubercles. Ulnar tubercles and folds absent; palmar tubercle flat and oval, approximately same length but twice the width of elongate, thenar tubercle; supernumerary palmar tubercles absent; subarticular tubercles prominent, ovoid in ventral view, rounded in lateral view, largest at base of fingers; fingers lacking lateral fringes; relative lengths of fingers $3>4>2>1$ (Fig. 3); tips of digits bulbous, not expanded laterally (Fig. 3); forearm lacking tubercles. 
and posterior surfaces of hindlimbs smooth with scattered, minute tubercles; heel without tarsus lacking tubercles; inner metatarsal tubercle, oval, high, and at least three times the size of defined; subarticular tubercles rounded, ovoid in ventral view; toes lacking lateral fringes, not webbed; toe tips weakly pointed, not expanded laterally; relative lengths of toes $4>3>5>2>$ 1 (Fig. 3); foot length $46.3 \%$ of SVL. with a dark brown X-shaped middorsal mark. The interorbital bar is a narrow dark stripe and is bordered anteriorly by a cream stripe. There is a dark brown subocular mark bordered by a thin cream line. A dark brown stripe, outlined below by a thin cream line extends from the tip of the snout to above the insertion of forelimb; from that point, a discontinuous dark line runs dorsolaterally separating dorsum from flank to the point of hind limb insertion. The iris is dark gray. The throat has brown coloration anteriorly, fading into pale grey with brown flecks and on the ventral parts of hind and forelimbs. The posterior surfaces of thighs are dark brown palmar surfaces are brown, but fingers and toes are cream. The dorsal surfaces of hind limbs

299 have transverse dark bars. 
Coloration of holotype in life. Similar to coloration in preservative, with the difference

302

303

304

305

306

307

308

309

310

311

312

313

314

315

316

317

318

319

320

321

322

Variation. Coloration in life is based on field notes and photographs taken by A.

Catenazzi of 23 collected and 21 uncollected specimens found at and near the type locality (Fig.

4, see Appendix3 for codes and photographsof uncollected specimens). There is substantial

variation in dorsal coloration, which varies from beige to grayish-tan and dark brown, and while most individuals have the X-shaped dorsal mark (barely noticeable in individuals with dark

coloration), several individuals have additional dark marks. The dark stripe extending dorsolaterally between the points of insertion of limbs is discontinuous in most individuals

(including the holotype) and absent in at least three specimens (CORBIDI 16496, 16504, and MHNC 14658), but at least ten specimens (CORBIDI 16497, 16499, 16506, MHNC 14668, $14671-72$, and uncollected $639.15,640.15,1019.15,10676.15)$ have a continuous stripe separating the lighter dorsal coloration from the darker coloration on the flanks. Sixteen individuals (36\%; including paratypes CORBIDI 16496-98, 16503-06, 16993-94, MHNC $14667,14670,14672$; and uncollected individuals $640.15,1005.15,1006.15,1065.15)$ have a yellow or orange middorsal line extending in most individuals from the interorbital bar (but from tip of snout in CORBIDI 16496, 16993-94, and uncollected 1065.15) to the cloaca, and from the cloaca along the posterior side of thighs to the knee. The throat is generally reddish-brown with 
323 yellow or orange flecks; CORBIDI 16992, 16496 and uncollected 1065.15 have a yellow or

324 orange line running midventrally from the tip of snout to the cloaca. Chest and ventral surfaces

325 of abdomen and limbs are yellow or orange with variable amounts of reddish-brown, brown or

326 grey flecks, especially on the chest. In some individuals (e.g., CORBIDI16504-06, 16994, and

327 uncollected 1018.15) background coloration on chest and belly is brown or gray with yellow

328 flecks.

329 The summary of measurements of all types is reported in Table 2. A histogram of the

330 frequency distribution of SVL for all captured specimens (types and uncollected specimens)

331 suggests modes of 20.0-21.9 $\mathrm{mm}$ for males and 24.0-25.9 $\mathrm{mm}$ for females (Fig. 6).

Advertisement call. The call of the holotype was recorded shortly before capture at

$33313 \mathrm{~h} 45$ on 21 June 2015 (Fig. 7). At a $\mathrm{T}_{\text {air }}=11.6^{\circ} \mathrm{C}$, the advertisement call averaged $3212 \pm 1005$

$334 \mathrm{~ms}$ in duration (range 1140-4524 ms) and consisted of $47.9 \pm 16.1$ single-pulsed notes (range 10-

68) produced at a rate of $14.7 \pm 1.8$ notes/s (range $8.77-16.55$ ). Peak frequency averaged $2712 \pm$

$33 \mathrm{~Hz}$ (range $2584-2885 \mathrm{~Hz}$ ) and increased during calls $\left(\mathrm{t}_{1,78}=-6.53, \mathrm{p}<0.01\right)$ : peak frequency averaged $2702 \pm 38 \mathrm{~Hz}$ for the first three notes, and $2748 \pm 50 \mathrm{~Hz}$ for the last three notes of each call. Amplitude also increased during each call, and the three final notes had amplitude $\sim 400 \%$ higher than the amplitude of the three initial notes. Average note duration was $5.4 \pm 1.2 \mathrm{~ms}$ (range 1-12 ms), but note duration increased from $2.6 \pm 0.7 \mathrm{~ms}$ in the first three notes to $7.8 \pm$

34226 calls produced at a rate of 9.43 calls/minute: the number of notes increased from 57 notes in

343 the first two calls to 68 notes in the $5^{\text {th }}$ call, and then progressively declined to 10 notes in the $34426^{\text {th }}$ call. 
Etymology. The name of the new species is a combination of Quechua words used in

347 apposition meaning "toad" ("hampa'tu") that lives in the "cold" ("chiri”). The name is a

wordplay built upon the genus and species names sharing the same meaning of "frog inhabiting

349 cold environments", because the generic name Psychrophrynella derives from the Greek

psychros (cold) and phrynos (toad).

351

352

Distribution, natural history and threats. The new species was found during amphibian

353

354

355

356

357

358

359

360

361

362

363

364

365

367

366 None of the 45 specimens of P. chirihampatu tested for Bd were infected. Similarly, two

surveys in the Japumato valley (Fig. 8A) conducted from 17 to 24 June 2015. We searched for frogs under rocks, logs, in the leaf litter and the understory along the transition from montane forest to high-Andean grassland (wet puna) from 2650 to $4600 \mathrm{~m}$. Specimens of $P$. chirihampatu were only found at elevations from 2650 to $3180 \mathrm{~m}$. Most specimens were found under rocks (many males were calling) during the day in areas of disturbed montane forest vegetation, such as the sides of the trail near the Tambo camp site (Fig. 8B), and natural landslides at the type locality (Fig. 8C) and at the Playa campsite. Field notes indicate that males were heard calling in similarly disturbed areas of the montane forest and along the edges of forest bordering landslides and other open areas.

We found an unattended nest of 11 eggs (Fig. 8D), diameter $4.5 \mathrm{~mm}$ on average, under a rock at the type locality. Ten female paratypes had 9.6 \pm 1.5 eggs (range 7-12 eggs) at different stages of maturation; of these, one had 10 mature eggs averaging $3.9 \pm 0.4 \mathrm{~mm}$ in diameter (range $3.5-4.6 \mathrm{~mm}$ ). sympatric species, Bryophryne zonalis $(\mathrm{n}=6)$ and Gastrotheca $\mathrm{cf}$. excubitor $(\mathrm{n}=10)$ were Bd- 
368 negative, as were Bryophryne sp. $(\mathrm{n}=4)$ from 3820-3050 $\mathrm{m}$ and an individual of Pleurodema 369 marmoratum from $4600 \mathrm{~m}$.

370 The upper Japumayo valley is part of the Área de Conservación Privada Ukumari Llaqta,

371 a protected area recognized by Peruvian environmental ministerial decree $\left(\mathrm{N}^{\circ} 301-2011\right.$ -

372 MINAM) in December 2011, and owned by the Comunidad Campesina Japu Q'eros. Therefore,

373 the known distribution range of the species is protected. Although the valley is used for

374 agricultural purposes, current land use appears to be sustainable and is unlikely to negatively

375 affect populations of $P$. chirihampatu. Given this species' affinity for disturbed areas, it is even

376 possible that the current anthropogenic use of the montane forest might enhance the distribution

377 of P. chirihampatu.

378 The current conservation status of P. chirihampatu is unknown. The populations we 379 surveyed in the Japumayo valley were relatively large: for example at the type locality we found 38025 frogs in 7 person-hours. We did not observe any direct threat to these populations during our 381 visit. In absence of more detailed data regarding its extent of occurrence, and according to the IUCN Red List criteria and categories (IUCN 2013), this species can provisionally be considered 383 for the "Data Deficient" category of the Red List.

\section{Discussion}

The new species is yet another addition to the ever growing list of small craugastorid

387 frogs (genera Bryophryne, Noblella and Psychrophrynella) from the eastern slopes of the Peruvian and Bolivian Andes (Catenazzi et al. 2015; De la Riva 2007; De la Riva and Burrowes 2014; De la Riva et al. 2008a; Harvey et al. 2013; Lehr and Catenazzi 2008; Lehr and Catenazzi 2009a; Lehr and Catenazzi 2009b; Lehr and Catenazzi 2010). Most if not all of these species 
391 have narrow distribution ranges often restricted to the type locality and surrounding mountaintop

392 region, although large areas in between the type localities of these species remain unexplored. It

393 is remarkable however that mountain passes separated by less than $50 \mathrm{~km}$ in airline distance do

394 not share any species of Bryophryne, Noblella or Psychrophrynella. Such high levels of observed

395 beta diversity, and the presence of unexplored regions suggest that more species remain to be 396 discovered.

397 We assign the new species to Psychrophrynella on the basis of shared meristic traits, 398 general body shape and appearance, and overall similarity with the type species $P$. bagrecito and 399 with P. usurpator. Interestingly, these two species shares with P. chirihampatu characters that 400 are absent in other congeneric forms, such as the presence of an elongated tubercle on the inner 401 edge of the tarsus, and an advertisement call composed of multiple notes. Further work is needed 402 to document variation in meristic traits and acoustic properties of advertisement calls in species of Psychrophrynella, as well as molecular analyses aimed at determining the phylogenetic 404 relationships of these species.

Although we did not detect the presence of Bd in the Japumayo valley, this fungus has 406 been reported from the nearby region of Abra Huallahualla and Coline (approximately $15-20 \mathrm{~km}$ SW by airline from the type locality of $P$. chirihampatu), where infected species included terrestrial-breeding B. zonalis, and aquatic-breeding P. marmoratum and Telmatobius marmoratus (Catenazzi et al. 2011). Furthermore, members of the Japu Q'eros Community who guided us to the type locality confirmed that T. marmoratus, a species known to be susceptible to chytridiomycosis (Catenazzi and von May 2014; Warne et al. 2016), was previously abundant in

412 the upper reach of the Japumayo valley, but had disappeared sometime during the last decade.

413 Therefore, it is likely that Bd has already reached, and possibly caused declines of other 
414 amphibian populations in the Japumayo valley. In the montane forests of Manu NP (70 km NW

415 of Japumayo), Bd has caused the local extinction of many stream-breeding species, but not of

416 terrestrial-breeding frogs such as Psychrophrynella spp (Catenazzi et al. 2011). These findings

417 suggest that Bd might not be as much of a threat for $P$. chirihampatu as it is for aquatic-breeding 418 frogs.

419 Species with narrow geographic distributions are intrinsically threatened, and they are 420 less likely to be included in nationally protected areas, as previously shown for Peru (Catenazzi 421 and von May 2014; von May et al. 2008). Smaller areas, but more widely dispersed in the

422 landscaspe, are needed to protect amphibian biodiversity in regions of high beta diversity such as 423 tropical Andean mountaintops. The introduction of new legal forms of protected areas in Peru, 424 such as conservation concessions, private and communal reserves, could greatly benefit 425 amphibian conservation. Discovery of endemic species provides justification for these reserves;

426 for example, the description of $P$. chirihampatu for the Área de Conservación Privada Ukumari 427 Llakta means that this reserve now protects at least one species of amphibian not found 428 anywhere else. Exploration of other private protected areas and conservation concessions will 429 generate similarly beneficial outcomes and will advance our knowledge of amphibian 430 biodiversity.

\section{Acknowledgements}

433 We thank the Comunidad Campesina Japu Q'eros for their hospitability, granting us access to 434 and guiding us through the Japumayo valley; and the Asociación para la Conservación de la 435 Cuenca Amazónica for logistical support, and especially Marlene Mamani for introducing us to 
436 the community and for coordinating our visit to Japu. We thank I. De la Riva and M.P. Heinicke

437 for comments on the manuscript.

438

439 References

440 Boyle DG, Boyle DB, Olsen V, Morgan JAT, Hyatt AD (2004) Rapid quantitative detection of 441 chytridiomycosis (Batrachochytrium dendrobatidis) in amphibian samples using real-

442 time Taqman PCR assay. Diseases of Aquatic Organisms 60: 141-148.

443 doi:10.3354/dao060141

444

445

Catenazzi A, Lehr E, Rodriguez LO, Vredenburg VT (2011) Batrachochytrium dendrobatidis and the collapse of anuran species richness and abundance in the upper Manu National Park, southeastern Peru. Conservation Biology 25: 382-391

447 Catenazzi A, Lehr E, Vredenburg VT (2014) Thermal physiology, disease and amphibian declines in the eastern slopes of the Andes. Conservation Biology 28: 509-517. doi:10.1111/cobi.12194

Catenazzi A, Uscapi V, von May R (2015) A new species of Noblella from the humid montane 451 forests of Cusco, Peru. Zookeys 516: 71-84

452 453

Catenazzi A, von May R (2014) Conservation status of amphibians in Peru. Herpetological Monographs 28: 1-23

454

De la Riva I (2007) Bolivian frogs of the genus Phrynopus, with the description of twelve new 455 species (Anura: Brachycephalidae). Herpetological Monographs 21: 241-277

De la Riva I, Burrowes PA (2014) A new species of Psychrophrynella (Anura: Craugastoridae) from the Cordillera Real, Department La Paz, Bolivia. Zootaxa 3887: 459-470. doi:10.11646/zootaxa.3887.4.4 
459 De la Riva I, Chaparro JC, Padial JM (2008a) A new, long-standing misidentified species of 460 Psychrophrynella Hedges, Duellman \& Heinicke from Departamento Cusco, Peru (Anura 461 : Strabomantidae). Zootaxa 1823: 42-50

462 De la Riva I, Chaparro JC, Padial JM (2008b) The taxonomic status of Phyllonastes Heyer and Phrynopus peruvianus (Noble) (Lissamphibia, Anura): resurrection of Noblella Barbour. Zootaxa 1685: 67-68

465

466

467

468

469

470

471

472

473

474

475

476

477

478

479

480 Tier Verlag, Münster, 382 pp.

Duellman WE, Lehr E, Venegas PJ (2006) Two new species of Eleutherodactylus (Anura: Leptodactylidae) from the Andes of northern Peru. Zootaxa 1285: 51-64

Amphibian Species of the World: an Online Reference. Version 6.0. http://research.amnh.org/herpetology/amphibia/index.html [accessed 28 November 2015.

Harvey MB, Almendáriz A, Brito M J, Batallas R D (2013) A new species of Noblella (Anura: Craugastoridae) from the Amazonian slopes of the Ecuadorian Andes with comments on Noblella lochites (Lynch). Zootaxa 3635: 1-14. doi:10.11646/zootaxa.3635.1.1

Hedges SB, Duellman WE, Heinicke MP (2008) New World direct-developing frogs (Anura: Terrarana): molecular phylogeny, classification, biogeography, and conservation. Zootaxa 1737: 1-182

Heinicke MP, Duellman WE, Hedges SB (2007) Major Caribbean and Central American frog faunas originated by ancient oceanic dispersal. Proceedings of the National Academy of Sciences of the United States of America 104: 10092-10097. doi:10.1073/pnas.0611051104 
481 Hyatt AD, Boyle DG, Olsen V, Boyle DB, Berger L, Obendorf D, Dalton A, Kriger K, Hero M,

482

483

484

485

486

487

488

489

490

491

492

493

494

495

496

497

498

499

500

501

502

Hines H, Phillott R, Campbell R, Marantelli G, Gleason F, Colling A (2007) Diagnostic assays and sampling protocols for the detection of Batrachochytrium dendrobatidis.

Diseases of Aquatic Organisms 73: 175-192. doi:10.3354/dao073175

IUCN (2013) Guidelines for using the IUCN Red List categories and criteria. - Version 10.1. Prepared by the Standards and Petitions Subcommittee. IUCN, pp.

Katoh K, Standley DM (2013) MAFFT multiple sequence alignment software version 7: improvements in performance and usability. Molecular Biology and Evolution 30: 772780

Kriger KM, Hero J-M, Ashton KJ (2006) Cost efficiency in the detection of chytridiomycosis using PCR assay. Diseases of Aquatic Organisms 71: 149-154. doi:10.3354/dao071149

Lehr E (2006) Taxonomic status of some species of Peruvian Phrynopus (Anura : Leptodactylidae), with the description of a new species from the Andes of Southern Peru. Herpetologica 62: 331-347. doi:10.1655/0018-0831(2006)62[331:tsosso]2.0.co;2

Lehr E, Catenazzi A (2008) A new species of Bryophryne (Anura: Strabomantidae) from southern Peru. Zootaxa 1784: 1-10

Lehr E, Catenazzi A (2009a) A new species of minute Noblella (Anura: Strabomantidae) from southern Peru: The smallest frog of the Andes. Copeia: 148-156. doi:10.1643/ch-07-270

Lehr E, Catenazzi A (2009b) Three new species of Bryophryne (Anura: Strabomantidae) from the Region of Cusco, Peru. South American Journal of Herpetology 4: 125-138

Lehr E, Catenazzi A (2010) Two new species of Bryophryne (Anura: Strabomantidae) from high elevations in southern Peru (Region of Cusco). Herpetologica 66: 308-319 
503 Lynch JD (1986) New species of minute leptodactylid frogs from the Andes of Ecuador and $504 \quad$ Peru. Journal of Herpetology 20: 423-431

505 Lynch JD, Duellman WE (1997) Frogs of the genus Eleutherodactylus in western Ecuador. 506 Systematics, ecology, and biogeography. The University of Kansas Special Publication

507

508

509

510

511

512

513

514

515

516

517

518

519

520

521

522

523

524

23: $1-236$

Noble GK (1921) Five new species of Salientia from South America. American Museum Novitates 29: 1-7

Padial JM, Grant T, Frost DR (2014) Molecular systematics of terraranas (Anura: Brachycephaloidea) with an assessment of the effects of alignment and optimality criteria. Zootaxa 3825: 1-132

Palumbi SR, Martin A, Romano S, McMillan WO, Stice L, Grabawski G (2002) The Simple Fool's Guide to PCR, Version 2.0. Privately published, compiled by S. Palumbi. University of Hawaii, Honolulu, pp.

Paradis E, Claude J, Strimmer K (2004) APE: analyses of phylogenetics and evolution in R language. Bioinformatics 20: 289-290

Pyron RA, Wiens JJ (2011) A large-scale phylogeny of Amphibia including over 2800 species, and a revised classification of extant frogs, salamanders, and caecilians. Molecular Phylogenetics and Evolution 61: 543-583. doi:10.1016/j.ympev.2011.06.012 von May R, Catenazzi A, Angulo A, Brown JL, Carrillo J, Chávez G, Córdova JH, Curo A, Delgado A, Enciso MA, Gutiérrez R, Lehr E, Martínez JL, Medina-Müller M, Miranda A, Neira DR, Ochoa JA, Quiroz AJ, Rodríguez DA, Rodríguez LO, Salas AW, Seimon T, Seimon A, Siu-Ting K, Suárez J, Torres C, Twomey E (2008) Current state of 
527 Warne RW, LaBumbard B, LaGrange S, Vredenburg VT, Catenazzi A (2016) Co-Infection by

528 chytrid fungus and Ranaviruses in wild and harvested frogs in the Tropical Andes. PLoS ONE 11: e0145864. doi:10.1371/journal.pone.0145864 


\section{Appendix 1. Gene sequences for molecular analyses}

533 Genbank accession numbers for the taxa and genes sampled in this study. Genbank accession

534 codes $(*)$ will be provided upon acceptance of the paper

\begin{tabular}{llc}
\hline Taxon & Voucher Nbr. & 16S \\
\hline Barycholos pulcher & KU 217781 & EU186709 \\
Bryophryne bakersfield & MHNC 5999 & KT276289 \\
Bryophryne bustamantei & MHNC 6019 & KT276293 \\
Bryophryne cophites & KU 173497 & F493537 \\
Holoaden luederwaldti & MZUSP 131872 & EU186710 \\
Noblella lochites & KU 177356 & EU186699 \\
Noblella myrmecoides & QCAZ 40180 & JX267542 \\
$\begin{array}{l}\text { Pyschrophrynella guillei } \\
\text { Pyschrophrynella usurpator }\end{array}$ & KMNH-A 165108 & AY843720 \\
$\begin{array}{l}\text { Pyschrophrynella wettsteini } \\
\text { Psychrophrynella }\end{array}$ & KU 183049 & F493714 \\
chirihampatu & & EU186696 \\
$\begin{array}{l}\text { Psychrophrynella } \\
\text { chirihampatu }\end{array}$ & MHNC 14664 & $(*)$ \\
\hline
\end{tabular}

535

536 
537 Appendix 2. Specimens examined

538 Noblella madreselva (2 specimens): PERU: CUSCO: Provincia La Convención, Madre Selva

539 (Santa Ana), CORBIDI 15769-70.

540

541 Noblella pygmaea (15 specimens): PERU: CUSCO: Provincia Paucartambo, Kosñipata, MHNG

542 2725.29-30, MUSM 24535-36, 26306-7, 26318-20, 30423-24, 30453-54, MTD 47286-87.

543

544 Psychrophrynella bagrecito (14 specimens): PERU: CUSCO: Quispicanchis: Marcapata, Río

545 Marcapata, below Marcapata, ca. 2740 m, KU 196512 (holotype), KU 196513-18, 196520-21,

546 196523-25 (all paratypes); La Convención: Hacienda Huyro between Huayopata and

547 Quillabamba, 1830 m, KU 196527-28.

548

549 Psychrophrynella usurpator (78 specimens): PERU: CUSCO: Provincia Paucartambo, Kosñipata, 550 MUSM 20011, 20873-81, 20896-20913, 20925-33, 20946-47, 20955-57, 21012-18, 26272-

$55173,26278-79,26308,27592,27906,27950,28033-28047,30303,30305,30396-30400,30405-$ 552 30409, 30471-30474.

553

554 
555 Appendix 3. Photographs of live types and live uncollected specimens.

556

557 A document with photographs of live types and uncollected specimens is available as 558 Supplemental File.

559 
560

561

562

563

564

565

566

567

568

569

570

571

572

573

574

575

576

577

578

579

580

581

582

\section{FIGURES}

Figure 1. Map of Peru indicating the type localities of Peruvian and western Bolivian species of Psychrophrynella: P. bagrecito (black square), P. boettgeri (black star), P. chirihampatu sp. n. (asterisk), P. guillei and P. saltator (white circle), P. kallawaya (white star), P. katantika (circle), and P. usurpator (triangle).

Figure 2. Live (A, C, E) and preserved (B, D, F) specimen of the holotype of Psychrophrynella chirihampatu sp. n., male CORBIDI 16495 (SVL $18.8 \mathrm{~mm}$ ) in dorsolateral (A, B), dorsal (C, D) and ventral (E, F) views. Photographs by A. Catenazzi.

Figure 3. Ventral views of hand (A) and foot (B) of holotype, CORBIDI 16495 (hand length 4.6 mm, foot length $8.7 \mathrm{~mm}$ ) of Psychrophrynella chirihampatu sp. n. Photographs by A. Catenazzi.

Figure 4. Dorsolateral and ventral views of four paratypes of Psychrophrynella chirihampatu sp.

n. showing variation in dorsal and ventral coloration. Male MHNC 14656 (A, B), Tambo Japu. Male MHNC 14667 (C, D), type locality. Female CORBIDI 16502 (E, F). Female CORBIDI 16499 (G, H). Photographs by A. Catenazzi.

Figure 5. (A) Principal components analysis of 5 meristic characters, and (B) relationship between head width and snout-vent length of 17 adult males of Psychrophrynella chirihampatu from the type locality and of 44 males P. usurpator from Abra Acjanaco, Manu National Park, Peru. 
583 Figure 6. Frequency distribution of snout-vent lengths for a sample of 23 types and 21

584 uncollected individuals of Psychrophrynella chirihampatu sp. n.

585

586 Figure 7. Advertisement call (two notes) of male CORBIDI 16495 (SVL $18.8 \mathrm{~mm}$ ), holotype of 587 Psychrophrynella chirihampatu sp. n., recorded at the type locality on $21 \mathrm{June} 2015\left(\mathrm{~T}_{\text {air }}=\right.$ $\left.58811.6^{\circ} \mathrm{C}\right)$.

589

590

Figure 8. Collection localities of Psychrophrynella chirihampatu sp. $\mathrm{n}$. in the upper Japumayo

591 valley (A; view from lookout at $3000 \mathrm{~m}$ ): frogs were found under mosses and rocks along the 592 trail at $3160 \mathrm{~m}(\mathbf{B})$, and under rocks in a natural landslide at the type locality at $2700 \mathrm{~m}(\mathbf{C})$, 593 including an unattended nest under a rock (D; $10 \notin$ coin is $20.5 \mathrm{~mm}$ in diameter). Photographs by 594 A. Catenazzi. 


\section{TABLES}

601

602 Table 1. Selected characters $(+=$ character present; $-=$ character absent $)$ and character

603 conditions among Bolivian (first column) and Peruvian (all other columns) species of 604 Psychrophrynella.

605

606 Table 2. Range and average ( \pm standard deviation) measurements (in $\mathrm{mm}$ ) of type series of 607 Psychrophrynella chirihampatu sp. n.

608

609

Table 3. Results from the Principal Component Analysis of 5 meristic characters (SVL, head

610 length, head width, tibia length, foot length) of adults of two populations of Psychrophrynella.

611 The highest loading for each component is in boldface.

612

613 Table 4. Genetic distances (uncorrected p-distances) estimated from the non-coding 16S rRNA

614 mitochondrial fragment between Psychrophrynella chirihampatu and related taxa (in boldface

615 the most closely related species) of the subfamily Holadeninae (Craugastoridae).

616

617

618 


\section{Figure 1 (on next page)}

Map of Peru indicating the type localities of Peruvian and western Bolivian species of Psychrophrynella.

Map of Peru indicating the type localities of Peruvian and western Bolivian species of

Psychrophrynella: P. bagrecito (black square), P. boettgeri (black star), P. chirihampatu sp. $\mathrm{n}$. (asterisk), P. guillei and P. saltator (white circle), P. kallawaya (white star), P. katantika (circle), and P. usurpator (triangle). 


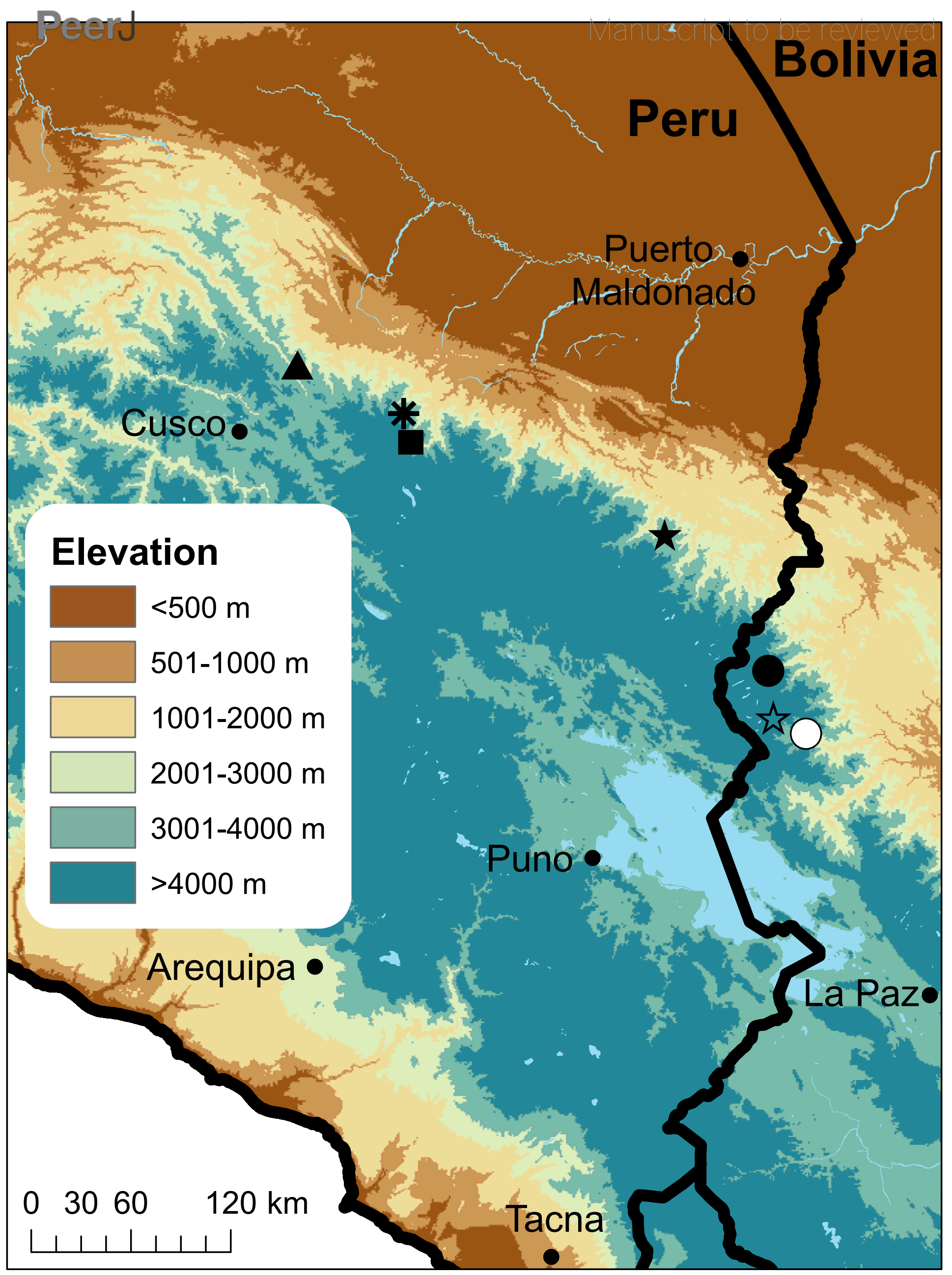


2

Photographs of live and preserved specimen of the holotype of Psychrophrynella chirihampatu.

Live (A, C, E) and preserved (B, D, F) specimen of the holotype of Psychrophrynella chirihampatu sp. n., male CORBIDI 16495 (SVL $18.8 \mathrm{~mm}$ ) in dorsolateral (A, B), dorsal (C, D) and ventral $(E, F)$ views. Photographs by $A$. Catenazzi. 

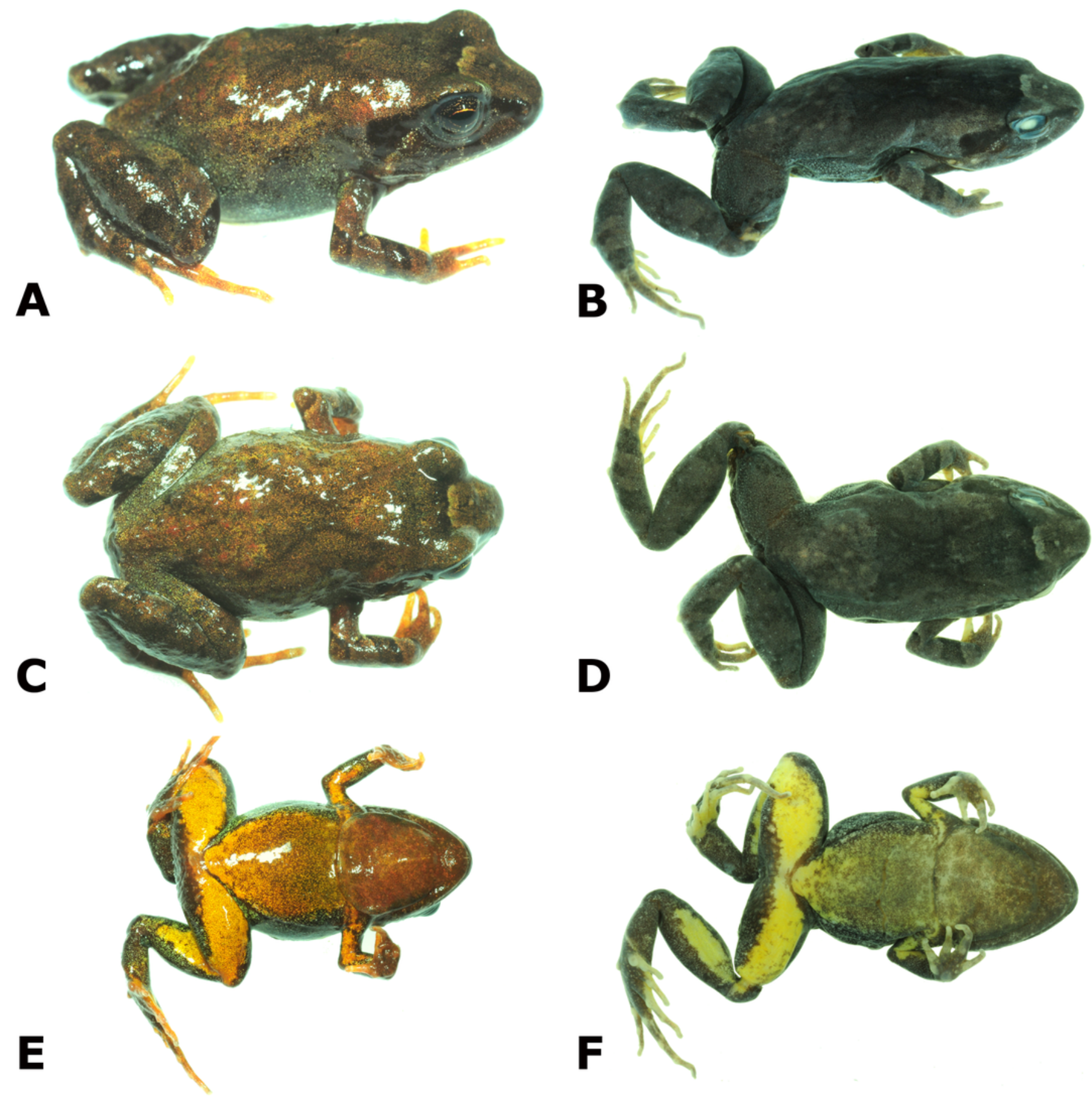
3

Palmar and plantar surfaces of the holotype of Psychrophrynella chirihampatu.

Ventral views of hand (A) and foot (B) of holotype, CORBIDI 16495 (hand length $4.6 \mathrm{~mm}$, foot length $8.7 \mathrm{~mm}$ ) of Psychrophrynella chirihampatu sp. n. Photographs by A. Catenazzi. .metri? $x \hat{c}$

\section{A}
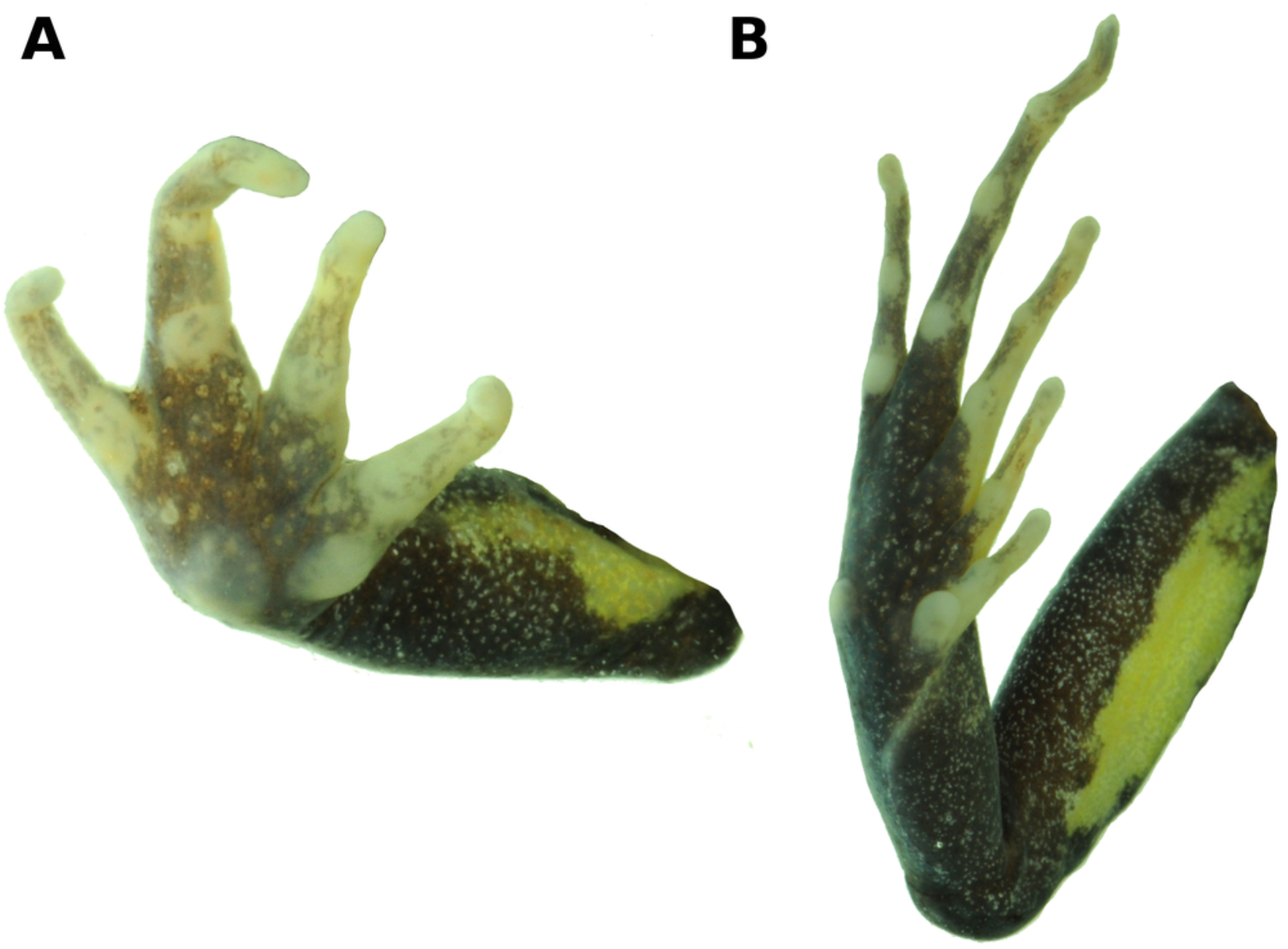
4

Dorsolateral and ventral views of four paratypes of Psychrophrynella chirihampatu.

Dorsolateral and ventral views of four paratypes of Psychrophrynella chirihampatu sp. $\mathrm{n}$. showing variation in dorsal and ventral coloration. Male MHNC 14656 (A, B), Tambo Japu. Male MHNC 14667 (C, D), type locality. Female CORBIDI 16502 (E, F). Female CORBIDI 16499 (G, H). Photographs by A. Catenazzi. 

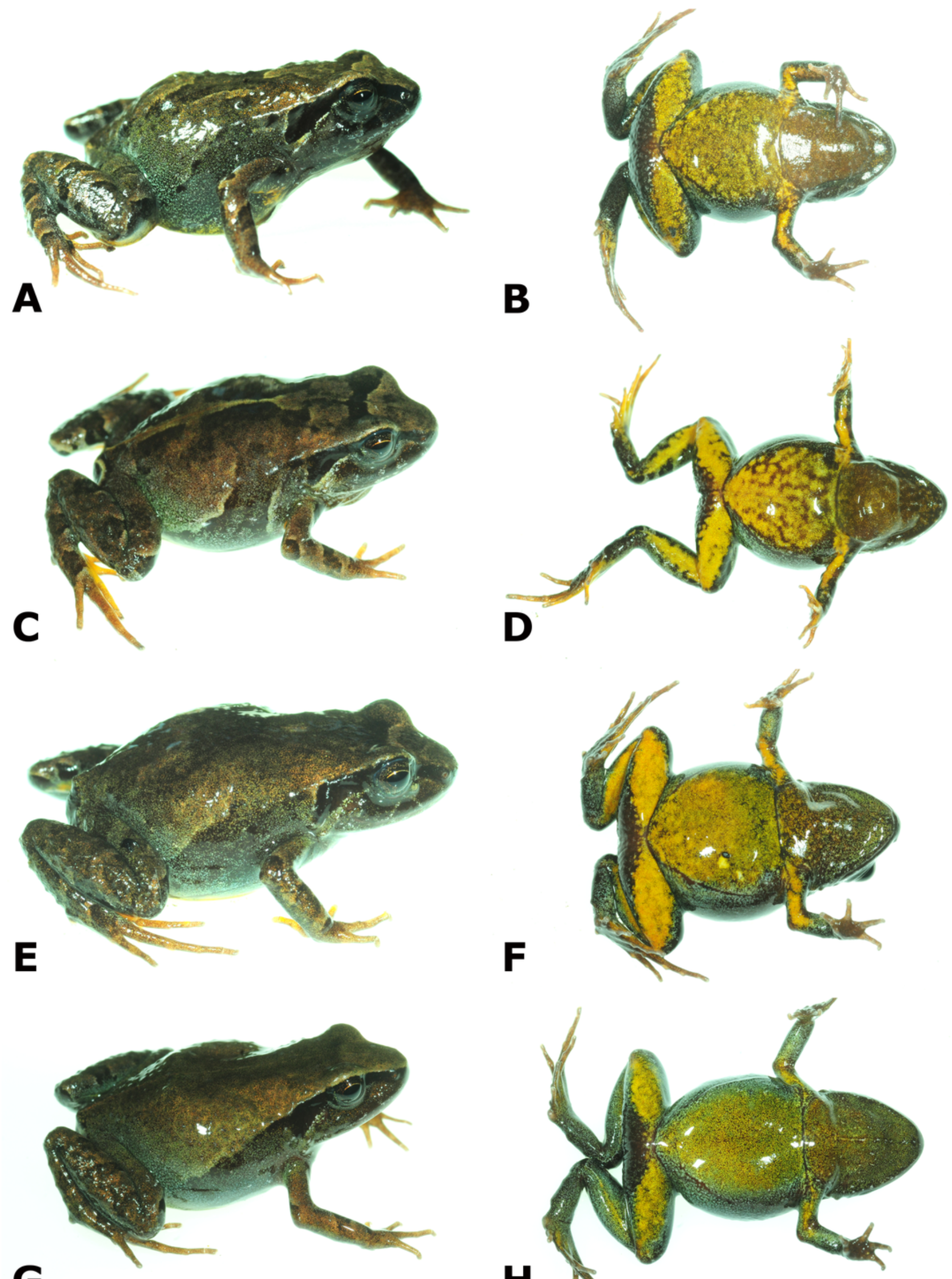

$\mathbf{G}$

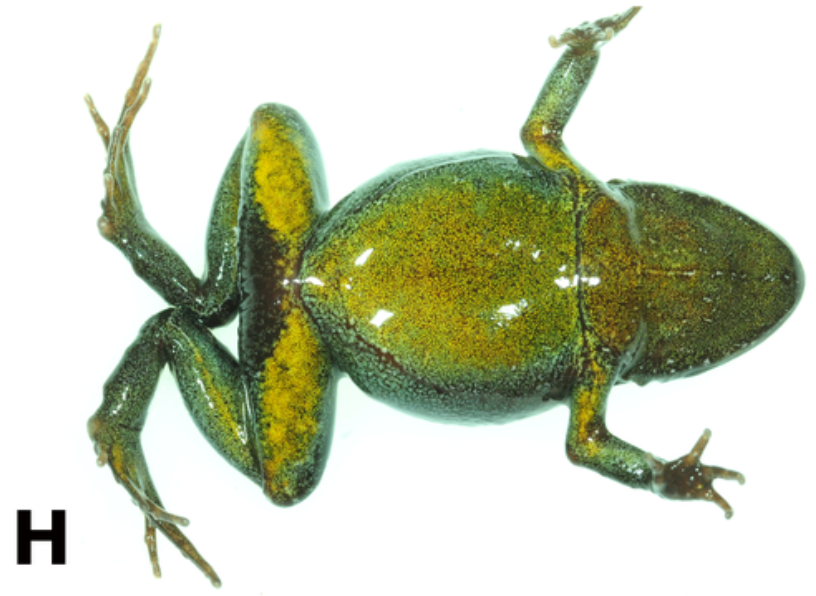


Figure $\mathbf{5}$ (on next page)

Morphometric comparisons between Psychrophrynella chirihampatu and P. usurpator.

(A) Principal components analysis of 5 meristic characters, and (B) relationship between head width and snout-vent length of 17 adult males of Psychrophrynella chirihampatu from the type locality and of 44 males P. usurpator from Abra Acjanaco, Manu National Park, Peru. 

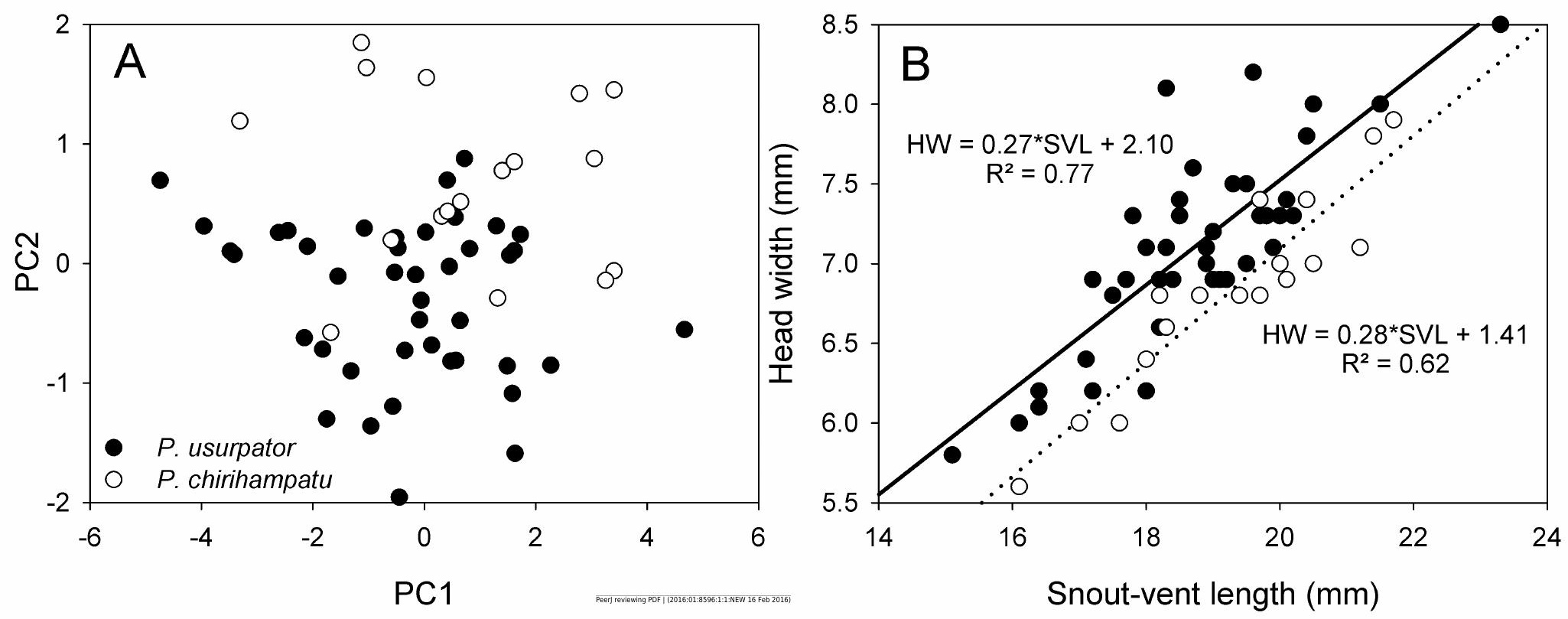


\section{Figure 6 (on next page)}

Frequency distribution of snout-vent lengths of Psychrophrynella chirihampatu .

Frequency distribution of snout-vent lengths for a sample of 23 types and 21 uncollected individuals of Psychrophrynella chirihampatu sp. $\mathrm{n}$. 


\section{7}

Advertisement call of Psychrophrynella chirihampatu.

Advertisement call (two notes) of male CORBIDI 16495 (SVL $18.8 \mathrm{~mm}$ ), holotype of

Psychrophrynella chirihampatu sp. n., recorded at the type locality on 21 June $2015\left(\mathrm{~T}_{\text {air }}=\right.$ $\left.11.6^{\circ} \mathrm{C}\right)$.

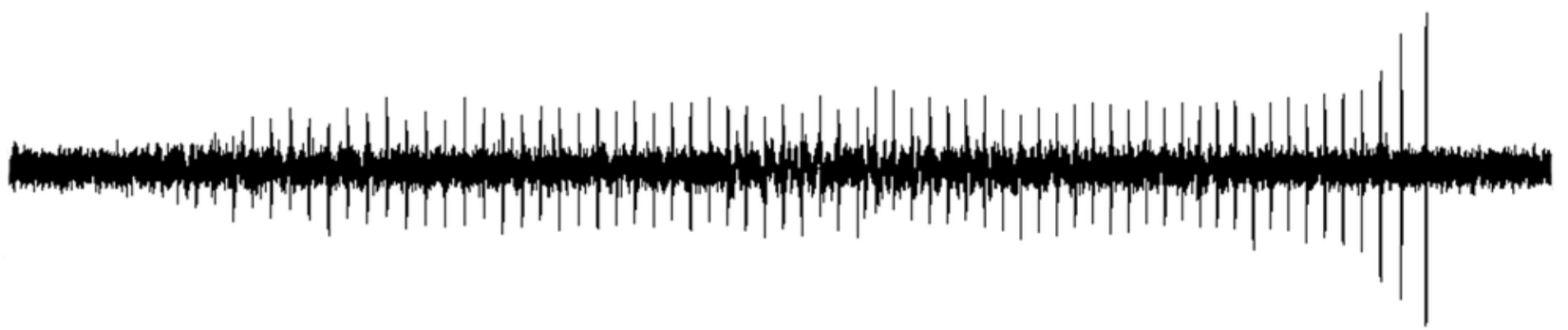

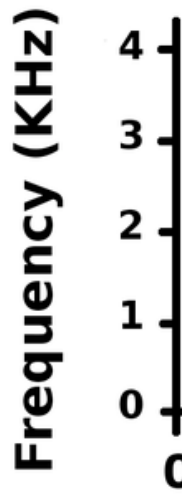

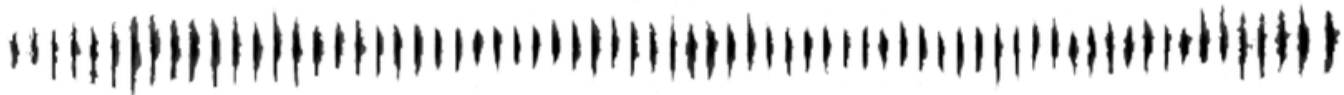

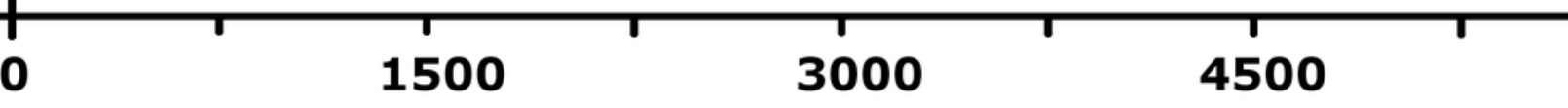

Time (milliseconds) 
8

Habitat and egg nest of Psychrophrynella chirihampatu .

Collection localities of Psychrophrynella chirihampatu sp. $\mathrm{n}$. in the upper Japumayo valley (A; view from lookout at $3000 \mathrm{~m}$ ): frogs were found under mosses and rocks along the trail at $3160 \mathrm{~m}$ (B), and under rocks in a natural landslide at the type locality at $2700 \mathrm{~m}$ (C), including an unattended nest under a rock (D; $10 \$$ coin is $20.5 \mathrm{~mm}$ in diameter). Photographs by A. Catenazzi.
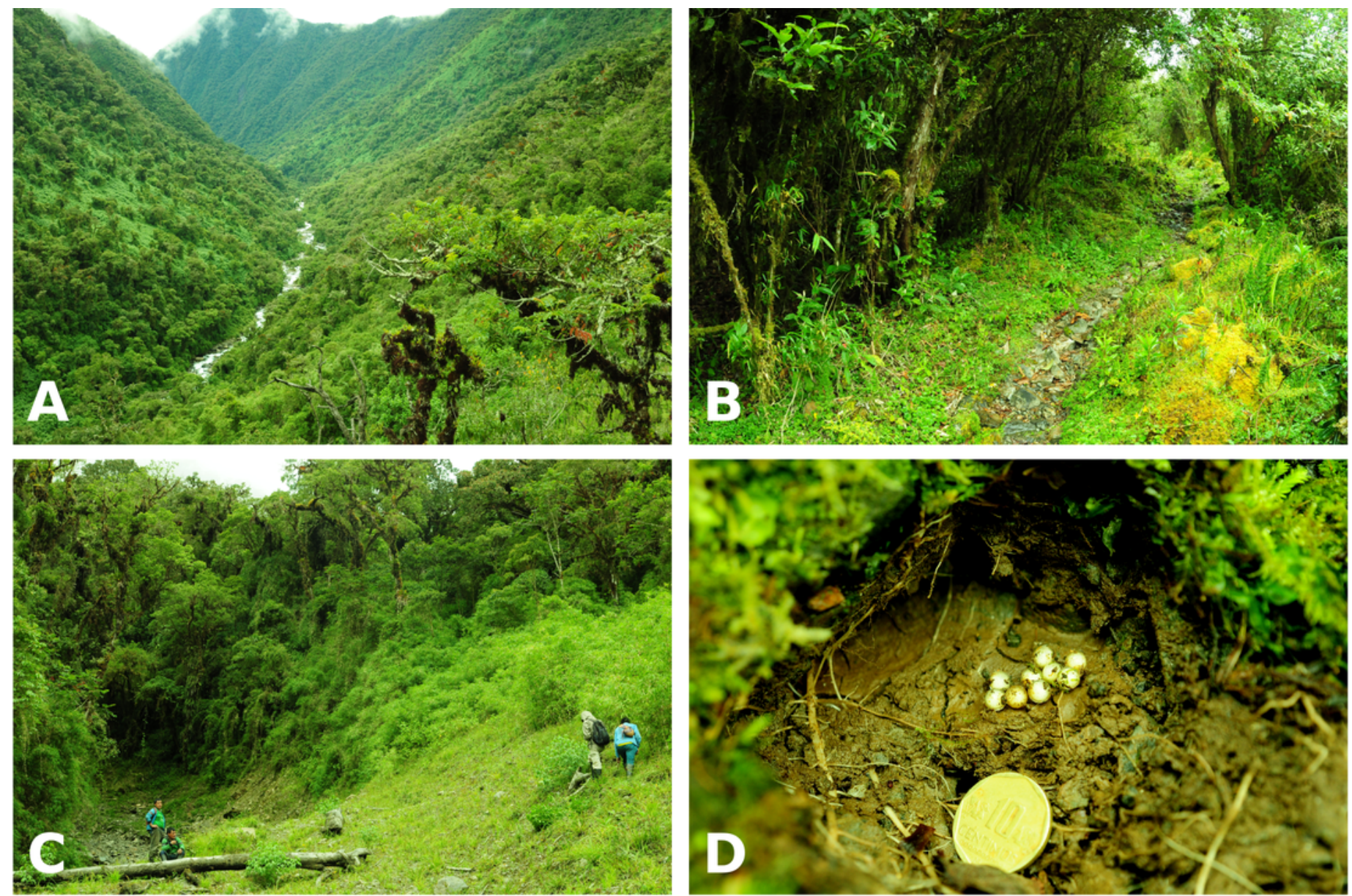


\section{Table $\mathbf{1}$ (on next page)}

Selected characters and character conditions in species of Psychrophrynella.

Selected characters $(+=$ character present; $-=$ character absent) and character conditions among Bolivian (first column) and Peruvian (all other columns) species of Psychrophrynella. 


\begin{tabular}{|c|c|c|c|c|c|}
\hline Characters & Bolivian spp. & P. bagrecito ${ }^{1}$ & P. boettgeri ${ }^{2}$ & $\begin{array}{c}P . \\
\text { chirihampatu }\end{array}$ & P. usurpator ${ }^{3}$ \\
\hline Maximum SVL (mm) & 19.0-30.9 & 19.0 & 18.4 & 27.7 & 30.5 \\
\hline Tympanic membrane & $\begin{array}{c}\text { not } \\
\text { differentiated }\end{array}$ & $\begin{array}{c}\text { not } \\
\text { differentiated }\end{array}$ & distinct & $\begin{array}{c}\text { not } \\
\text { differentiated }\end{array}$ & $\begin{array}{c}\text { not } \\
\text { differentiated }\end{array}$ \\
\hline Vomerine teeth & - & - & - & - & - \\
\hline Dorsolateral folds & variable & weak, anterior & + & weak, anterior & weak, anterior \\
\hline & & only & & only & only \\
\hline Vocal sac & variable & + & $?$ & + & + \\
\hline Vocal slits & variable & + & - & + & + \\
\hline Nuptial pads & - & - & - & - & - \\
\hline Finger I vs. II & variable & shorter & shorter & shorter & $\begin{array}{c}\text { slightly shorter } \\
\text { or equal }\end{array}$ \\
\hline Inner tarsal tubercle & - & sickle-shaped & - & elongated & elongated \\
\hline Ventral coloration & variable & $\begin{array}{c}\text { white, brown } \\
\text { marks }\end{array}$ & $\begin{array}{c}\text { brown and } \\
\text { cream }\end{array}$ & $\begin{array}{c}\text { yellow, brown } \\
\text { flecks }\end{array}$ & $\begin{array}{l}\text { brown or tan, } \\
\text { cream flecks }\end{array}$ \\
\hline Call & single note ${ }^{4}$ & multiple notes ${ }^{5}$ & $?$ & multiple notes & multiple notes ${ }^{5}$ \\
\hline \multicolumn{6}{|c|}{$\begin{array}{l}1 \text { Sample size for SVL is } 17 \text { individuals measured from } 1999 \text { to } 2009 \text { (unpublished data). } \\
{ }^{2} \text { Source: Lehr (2006). } \\
{ }^{3} \text { Sample size for SVL is } 811 \text { individuals measured from } 1996 \text { to } 2015 \text { (unpublished data). } \\
{ }^{4} \text { Except for } P \text {. saltator and } P \text {. taqta. } \\
5 \text { Unpublished data. }\end{array}$} \\
\hline
\end{tabular}


Table 2(on next page)

Measurements of type series of Psychrophrynella chirihampatu

Range and average ( \pm standard deviation) measurements (in $\mathrm{mm}$ ) of type series of Psychrophrynella chirihampatu sp. n. 


\begin{tabular}{|c|c|c|}
\hline Characters & Females $(n=10)$ & Males $(n=17)$ \\
\hline SVL & $23.9-25.8(25.0 \pm 0.6)$ & $16.1-21.7(19.3 \pm 1.6)$ \\
\hline TL & $10.2-11.0(10.8 \pm 0.2)$ & $8.0-10.1(9.0 \pm 0.6)$ \\
\hline FL & $10.3-11.5(11.0 \pm 0.4)$ & $7.1-10.4(9.3 \pm 0.8)$ \\
\hline HL & $8.0-9.0(8.5 \pm 0.3)$ & $6.3-8.1(7.3 \pm 0.5)$ \\
\hline HW & $7.4-7.8(7.6 \pm 0.4)$ & $5.6-7.9(6.8 \pm 0.6)$ \\
\hline ED & $2.5-2.8(2.7 \pm 0.1)$ & $2.0-2.5(2.2 \pm 0.2)$ \\
\hline IOD & $2.5-2.8(2.7 \pm 0.1)$ & $1.8-2.4(2.1 \pm 0.2)$ \\
\hline EW & $1.6-2.0(1.8 \pm 0.1)$ & $1.2-1.8(1.4 \pm 0.2)$ \\
\hline IND & $2.3-2.7(2.5 \pm 0.1)$ & $1.8-2.2(2.0 \pm 0.1)$ \\
\hline $\mathrm{E}-\mathrm{N}$ & $2.0-2.3(2.1 \pm 0.1)$ & $1.5-2.0(1.7 \pm 0.1)$ \\
\hline TL/SVL & $0.42-0.44$ & $0.43-0.52$ \\
\hline FL/SVL & $0.42-0.46$ & $0.39-0.54$ \\
\hline HL/SVL & $0.35-0.38$ & $0.34-0.40$ \\
\hline HW/SVL & $0.32-0.36$ & $0.33-0.38$ \\
\hline $\mathrm{HW} / \mathrm{HL}$ & $0.91-0.98$ & $0.88-1.07$ \\
\hline $\mathrm{E}-\mathrm{N} / \mathrm{ED}$ & $0.71-0.85$ & $0.68-0.90$ \\
\hline EW/IOD & $0.64-0.71$ & $0.58-0.75$ \\
\hline
\end{tabular}




\section{Table 3(on next page)}

Results of Principal Component Analysis of 5 meristic characters of two populations of Psychrophrynella.

Results from the Principal Component Analysis of 5 meristic characters (SVL, head length, head width, tibia length, foot length) of male adults of two populations of Psychrophrynella. The highest loading for each component is in boldface. 


\begin{tabular}{lccccc}
\hline \multicolumn{1}{c}{ Component } & PC1 & PC2 & PC3 & PC4 & PC5 \\
\hline Loadings & & & & & \\
Snout-vent length & $\mathbf{0 . 4 9}$ & -0.22 & -0.01 & 0.00 & $\mathbf{- 0 . 8 4}$ \\
Tibia length & 0.46 & 0.38 & -0.05 & $\mathbf{- 0 . 7 9}$ & 0.17 \\
Foot length & 0.44 & 0.45 & -0.54 & 0.53 & 0.15 \\
Head length & 0.45 & 0.09 & $\mathbf{0 . 8 0}$ & 0.31 & 0.23 \\
Head width & 0.39 & $\mathbf{- 0 . 7 7}$ & -0.25 & -0.03 & 0.43 \\
Importance of components & & & & & \\
Standard deviation & 1.93 & 0.81 & 0.57 & 0.45 & 0.32 \\
Proportion of variance & 0.74 & 0.13 & 0.07 & 0.04 & 0.02 \\
Cumulative proportion & 0.74 & 0.87 & 0.94 & 0.98 & 1.00 \\
\end{tabular}

1 


\section{Table 4(on next page)}

Genetic distances from 16S data

Genetic distances (uncorrected p-distances) estimated from the non-coding 16S rRNA mitochondrial fragment between Psychrophrynella chirihampatu and related taxa (in boldface the most closely related species) of the subfamily Holadeninae (Craugastoridae). 
Bryophryne bakersfield

Bryophryne bustamantei

Bryophryne cophites

Barycholos pulcher

Holoaden luederwaldti

Noblella lochites

Noblella myrmecoides

P. guillei

P. usurpator

P. wettsteini

P. chirihampatu MHNC14664

P. chirihampatu (holotype)

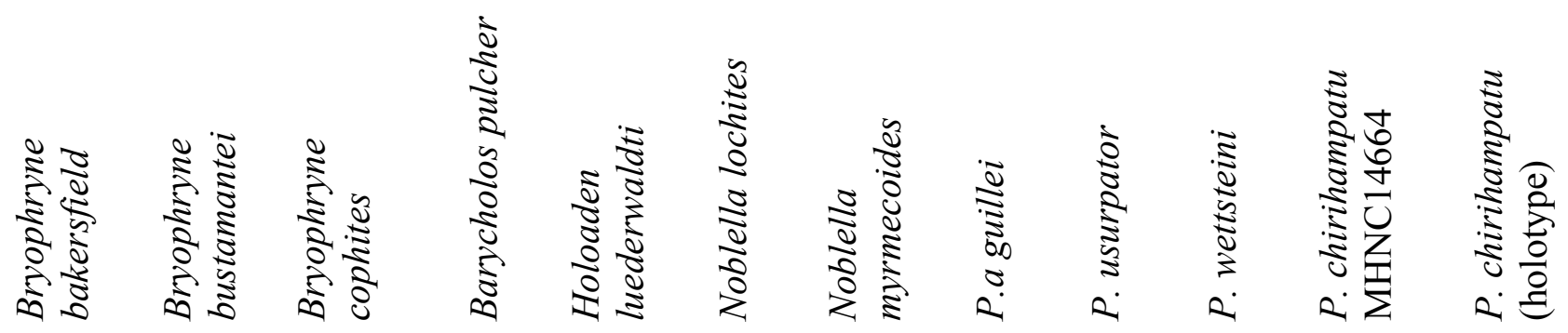
0 $0.06 \quad 0$

$0.04 \quad 0.17 \quad 0$

$\begin{array}{llll}0.21 & 0.30 & 0.29 & 0\end{array}$

$\begin{array}{lllll}0.19 & 0.26 & 0.24 & 0.30 & 0\end{array}$

0.23

0.17

0.29

0.26

0.27

0.25

0.18

0.30

0.28

0.27

$\begin{array}{ll}0.29 & 0.22\end{array}$

$\begin{array}{ll}0.24 & 0.29\end{array}$

0.21

$\begin{array}{lll}0.15 & 0.26 & 0.29\end{array}$

$\begin{array}{ll}0.25 & 0.31\end{array}$

0.20

$\begin{array}{llll}0.24 & 0.31 & 0.23 & 0.29\end{array}$

0.20

0.20

0.22

$0.19 \quad 0.25$

$\begin{array}{ll}0.20 & 0.21\end{array}$

$\begin{array}{lllll}0.19 & 0.25 & 0.20 & 0.22\end{array}$

$\begin{array}{rrrr}0 & & & \\ 0.30 & 0 & & \\ 0.29 & 0.23 & 0 & \\ 0.28 & 0.14 & 0.23 & 0 \\ \mathbf{0 . 1 8} & \mathbf{0 . 1 8} & \mathbf{0 . 0 7} & 0.19 \\ \mathbf{0 . 1 8} & \mathbf{0 . 1 8} & \mathbf{0 . 0 7} & 0.19\end{array}$

$\mathbf{0 . 0 0}$ 